\title{
Design, Fabrication and Characterization of a Commercially Prepared Carboxyl Multiwalled Carbon Nanotubes With a Hybrid Polymer Electrolytes
}

\author{
M. A. $\operatorname{Hashim}^{1} \&$ Lawal Sa'adu ${ }^{1}$ \\ ${ }^{1}$ Faculty of Science and Technology, Universiti Sains Islam Malaysia (USIM), Malaysia \\ Correspondence: Lawal Sa'adu, Faculty of Science and Technology, Universiti Sains Islam Malaysia (USIM), \\ Bandar Baru Nilai, Negeri Sembilan 71800, Malaysia. E-mail: lawals2004@gmail.com
}

Received: July 9, 2014 Accepted: July 20, 2014 Online Published: July 28, 2014

doi:10.5539/apr.v6n4p106

URL: http://dx.doi.org/10.5539/apr.v6n4p106

\begin{abstract}
We reported the fabrication of three different supercapacitor cells using a commercially prepared carboxyl multiwalled carbon nanotubes (CPCMWCNTs) as electrode, and hybrid solid polymer electrolytes (HSPE) of different electrical conductivities as separators. The Three cells were then constructed and leveled as cell-A (C90PVdF-HFP10 |H50| C90PVdF-HFP10), cell-B (C90PVdF-HFP10|H60| C90PVdF-HFP10) and cell-C (C90PVdF-HFP10 $|\mathrm{H} 70|$ C90PVdF-HFP10). Numbers of analysis, such as FESEM, XRD, TGA and electrochemical analysis were carried out on both the commercial CNT and that of the electrolytes. From the overall results of the electrochemical analysis of cyclic voltammetry $(\mathrm{CV})$, cell-B delivered higher capacitance of $60.10 \mathrm{Fg}^{-1}$ doubling that of cell-A, and tripling cell-C. Whereas the charge-discharge (CD) tests carried out in the cells reveals that even at the lower voltage window of $1.5 \mathrm{~V}$, cell-A delivered slightly better than that of $\mathrm{B}$ and $\mathrm{C}$ with a balanced and good discharge capacitance of $86.06 \mathrm{Fg}^{-1}$ and higher energy/power densities of 432.22 $\mathrm{Jg}^{-1} / 8.37 \mathrm{Jg}^{-1} \mathrm{~s}^{-1}$ and less internal resistance. All the cells were able to deliver a modest capacitance at a voltage window of $3 \mathrm{~V}$.
\end{abstract}

Keywords: supercapacitor, hybrid solid polymer electrolyte (HSPE), carboxyl multiwalled carbon nanotubes. Differential Scanning Calorimetry (DSC) analysis, cyclic voltammetry (CV), charge discharge (CD)

\section{Introduction}

Experts in the energy and its usage have identified the recognition of energy, pattern of consuming energy (Paul et al., 2012), the role of industry structure and its values as an energy paradigm change of the globe, with many of them, suggesting and developing a new paradigm, which occurred as a result of the complicated problems such as petroleum exhaustion, environmental pollution, greenhouse effect and climate change. They, however, forecasted that, the future energy paradigm will include concepts that diminishing wasteful energy, enriching the lifestyle and not burdening the environment (Iwama et al., 2012). All these, is in order to pave away to the few prominent energy storage devices such as batteries and most importantly "Supercapacitor" which could be one among the most efficiently used sustainable paradigm which also could tackle the current paradigm (Choi et al., 2012; Dubal et al., 2012).

Supercapacitors, also known as ultracapacitors (Inagaki et al., 2014a; Hashim \& Khiar, 2011; Burke, 2009) or power capacitors, store electrochemical energy by accumulating the charge from electric double layer, which is caused by electrostatic attraction. In this case, the capacity of the supercapacitor is proportional to the electrode surface, i.e., the electrochemically active surface, where, how much ions are attracted, (Gund et al., 2013; Jiang et al., 2013). Electrochemical Double Layer Capacitors (EDLCs) are possible to be fully charged and discharged in seconds. Although their energy density (about $5-10 \mathrm{Whkg}^{-1}$ ) is lower than in batteries or fuel cells, higher power density $\left(10 \mathrm{Whkg}^{-1}\right)$ can be reached in a short time (Choi et al., 201). The most attractive advantage of EDLCs is a high power capability (Ayad et al., 2011; Domingo-Garcia et al., 2010; Snook et al., 2011;) with the fast charge/discharge rate (Zheng et al., 2012; Choi et al., 2012). Moreover, most of the EDLCs are safer against short circuit than batteries in terms of the possibility of self-ignition. They do not contain any hazardous or toxic materials (Aravinda et al., 2013a; Aravinda et al., 2013b) and have the durability during long CD cycles. 
Basically supercapacitors can be represented by two distinct mechanisms describing them: (i) EDLC and (ii) Psuedocapacitor. EDLCs store the charge electrostatically following a reversible adsorption-desorption cycles of electrolyte ions onto active electrode materials. These active materials might not only be electrochemically stable, but also have accessible large surface area and with no any Faradaic reaction at EDLC electrode. The surface storage mechanism allows very fast energy uptake and delivery, and better power performance. However, the physicochemical process and electrode polarization in EDLC are not enough to apply high energy devices. On the other hand, pseudocapacitors, undergoes reversible Faradaic reactions. Chemically modified carbon materials, (Inagaki et al., 2014 b; Inagaki, 2012; Inagaki et al., 2014 c; Inagaki et al., 2014d; Inagaki et al., 2014 e), metal oxide, (Choi et al., 2012; Paul el al., 2012) and conducting polymers (Hsieh et al., 2012; Choi et al., 2012; Paul el al., 2012) are used as electrodes. In case of pseudocapacitors, the stability for charge-discharge (CD) cycling is relatively poor, though, their energy densities are relatively high compared to EDLCs. Furthermore, the response time is longer than EDLCs, because it takes longer time to move electrons during the redox reaction (Choi et al., 2012). Although supercapacitors can be regarded as "still evolving" into the area of ever more energy containing and powerful devices, they have since been able to address the increasing needs of electronic (cell phones, digital cameras, etc. (Probstle et al., 2002), industrial (uninterruptible power supplies, grid conditioning, windmills, cranes, etc.) (Payman et al., 2008; Wu et al., 2012) and in the sectors of transportation/automotive (trains, busses, cars) (Shi et al., 2013; Tran et al., 2013; Wu et al., 2013; Inagaki et al., 2014). Although supercapacitors have higher capacity than batteries and capacitors, it may present disadvantage of high raw material cost and process difficulty. However the application of thin film processes to the fabrication of the supercapacitors might overcome the above disadvantage. As a result, supercapacitors in thin film form (and using solid and flexible electrolyte) (Wang et al., 2013) are gaining increasing interest in the field of lightweight, ultrathin energy management devices for wearable electronics (Dubal et al., 2012). So far most of the current supercapacitors uses liquid electrolyte which could have side effect on the environment in terms of its hazards; the housing of the cell after the sealing of the electrolyte could also be another issue (Wang et al., 2013), the reason why we chose the former method for the cell fabrication.

Recently, number of researchers have diverted their attentions towards the development of advanced electrode materials, which could replace the most commonly used once (such as Activated Carbon (AC)), by mainly using Carbon Nanotubes (CNTs) networks or graphene as flexible electrodes, for high-performance flexible supercapacitors. CNTs, especially MWCNTs have high inherent conductivity, flexibility, chemical and mechanical stability, and larger surface area polarizability (Paul et al., 2012), and can operate within the voltage window of $3 \mathrm{~V}$ or more. Furthermore, their predominant exohedral surface favors the quick accumulation and transport of electrolyte ions so as to increase the performance of quick charge and discharge under high currents (Zheng et al., 2012). This will be vindicated in our cell construction and fabrication highlighted in this paper. In order to reduce the toxic effect to the environment and its inhabitants, (Dumortier et al., 2006) functionalized CNTs were selected for this purpose. Functionalized CNTs are said to be stable for long-term storage, are soluble in aqueous solution, have low toxicity, (Capek, 2009), while increasing more reactivity at their surface walls (Prato et al., 2007; Mittal, 2011). Most importantly, when CNTs are functionalized, their pore sizes will be widened up, thereby increasing the chances of ionic penetration at the electrode-electrolyte interface of fabricated supercapacitor (Van Hooijdonk et al., 2013).

\section{Experimental}

\subsection{Electrolytic Materials}

Hybrid Solid Polymer Electrolyte (HSPE) was prepared from a percentage ratio of 70:30, 60:40 and 50:50 wt. \% respectively of $\mathrm{PVA}$ and $\mathrm{H}_{3} \mathrm{PO}_{4}$ with cellulose filter paper immersed into it. $\mathrm{The}_{3} \mathrm{HO}_{4}(>85 \mathrm{wt} . \%$ in water, molar mass of $98.00 \mathrm{~g} \mathrm{Mol}^{-1}$, product, number of 1502-80) was obtained in aqueous form from R \& M marketing, Essex, UK brand, while the PVA (molecular weight; 89,000-98,000, $99+\%$ hydrolyzed) was obtained from Sigma Aldrich. Both $\mathrm{H}_{3} \mathrm{PO}_{4}$ and PVA were used as-received without further treatment or purification. An aqueous solution of PVA was then prepared by combining PVA with distilled water in the ratio of 1:10 by volume. This solution is mechanically agitated by magnetic stirring at $60^{\circ} \mathrm{C}$ for five hours to thoroughly dissolve the PVA in the distilled water. $\mathrm{H}_{3} \mathrm{PO}_{4}$ was then mixed with the PVA aqueous solution in the ratio of 70:30, 60:40 and 50:50 wt. \% as mentioned above. After the mixture cools to a room temperature, the resulting homogenous solution of $\mathrm{PVA} / \mathrm{H}_{3} \mathrm{PO}_{4}$ was cast over a plastic Petri dish. This was after a cellulose filter paper (Whatman brand) was cut into a $6 \mathrm{~cm} \times 5.5 \mathrm{~cm}$ and soaked in a segment of the aforementioned solution. The above mixture took roughly four weeks before it dries. After which it can be able to peel off was used as the separator and at the same time as the HSPE. 


\subsection{Electrode Materials and Cell Assembly}

The carboxyl multiwalled CNTs with the following specifications; -COOH content of 0.49 wt.\%, an outer diameter of $>50 \mathrm{~nm}$, length of $10-20 \mu \mathrm{m}$, purity and Ash are both $>95 \mathrm{wt} . \%$, and $<1.5 \mathrm{wt} . \%$, respectively, Surface area of $>40 \mathrm{~m}^{2} \mathrm{~g}^{-1}$ and Conductivity of $>10^{2} \mathrm{Scm}^{-1}$ was purchased locally in Malaysia (with material code MC8/21/20). The binder used, was P(VdF-HFP) (average molecular weight of $\sim 400,000$; Mn of $\sim 130,000$ pellets; product number of 427160) was purchased from Sigma Aldrich. So, the double layer capacitor was made with a mixture of $90 \mathrm{wt}$. \% of the CPCMWCNTs and $10 \mathrm{wt}$. \% of P(VdF-HFP), mixed inside a $20 \mathrm{ml}$ of the acetone. The slurry was then cast onto to the Aluminum foil and allowed to dry for about two hours at room temperature. Prior to that, an applicator was used to polish the slurry with the view to leveling it and obtaining a desired thickness which was around $0.127 \mathrm{~mm}$. The dried sample was then further dried in an oven for about 12 hours at a temperature of $100{ }^{\circ} \mathrm{C}$. Afterward, the solid films were obtained and were further cut into $2 \mathrm{~cm}^{2} \times 3 \mathrm{~cm}^{2}$ each. The weights of the films were measured by means of a micro-balance (Santorius, Ax 224) with an accuracy of $0.001 \mathrm{mg}$. The average weights of two electrode films that make a cell was around $0.224 \mathrm{~g}$. Using a Perspex of about $5 \mathrm{~cm} \mathrm{x} 4 \mathrm{~cm}$, the cell was set up by sandwiching two electrodes with the electrolyte and assembled in an innovative supercapacitor tester (see Figure 1).

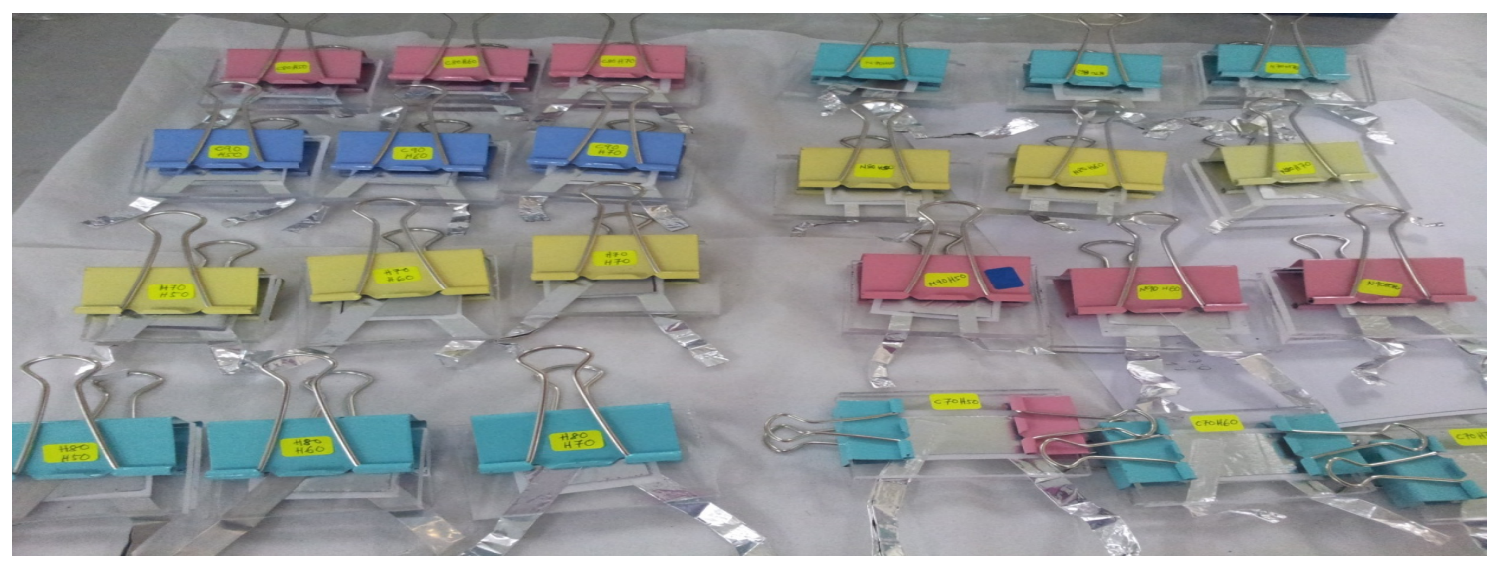

Figure 1. Cross-section of the fabricated supercapacitor cells in our laboratory

The surface morphologies of all films were investigated via FESEM (SU 8030 a family member of SU 8000; Resolution capability of $1.0 \mathrm{~nm} / 15 \mathrm{kV}, 1.3 \mathrm{~nm} / 1 \mathrm{kV}$ and abling magnification of 80x to 2000 000x). XRD spectra were obtained with an XRD (Philip X'Pert XRD with $\mathrm{Cu} \mathrm{K}_{\alpha}$ radiation of wavelength $\lambda=1.54056 \AA$ for $2 \boldsymbol{\theta}$ angles between $10^{\circ}$ and $80^{\circ}$ ) that used $\mathrm{Cu} \mathrm{K \alpha}$ radiation $(\lambda=1.5406 \AA$ ) operating at $40 \mathrm{kV}$ and $30 \mathrm{~mA}$. CD analysis and $\mathrm{CV}$ were respectively carried out by using a newer battery which has been interfaced to a computer called "e-machines" (model: ET1850, Rating: 100-127/220-240Vac, 6/3.15A (6/3,15A), 60/50 Hz) and Gamry instrument Framework (version 5.61).

The following symmetric capacitor cells were assembled

\section{Cells: Cell A - C90PVdF-HFP10 | H50|C90PVdF-HFP10 Cell B - C90PVdF-HFP10| H60| C90PVdF-HFP10 Cell C - C90PVdF-HFP10 | H70 | C90PVdF-HFP10}

\section{Results and Discussions}

\subsection{Microstructure Characterizations}

As mention earlier, XRD spectra were obtained with an XRD (Philip X'Pert XRD with $\mathrm{Cu} \mathrm{K}_{\alpha}$ radiation of wavelength $\lambda=1.54056 \AA$ for $2 \theta$ angles between $10^{\circ}$ and $\left.80^{\circ}\right)$ that used $\mathrm{Cu} \mathrm{K \alpha}$ radiation $(\lambda=1.5406 \AA$ ) operating at $40 \mathrm{kV}$ and $30 \mathrm{~mA}$. The XRD analysis of the C90PVdF-HFP10 electrode is depicted in Figure 2. As seen from 
this figure, all the diffraction peaks can be observed and the major diffraction peaks of the CPCMWCNT can also be seen clearly. The XRD peaks that appear in $\theta=26^{\circ}$ and $\theta=43^{\circ}$ might be as a result of the hexagonal structure of (002) and (101) respectively, which indicates that the carboxyl multiwalled CNT have high conductivity (Dong et al., 2007). In addition, there appeared a wider diffraction at $\theta=20.1^{\circ}$ which correspond to crystalline peaks of PVDF (Stolarska et al., 2007). This also results proved well with the same result of the XRD obtained by many researchers such as (Li et al., 2010; Stolarska et al., 2007).

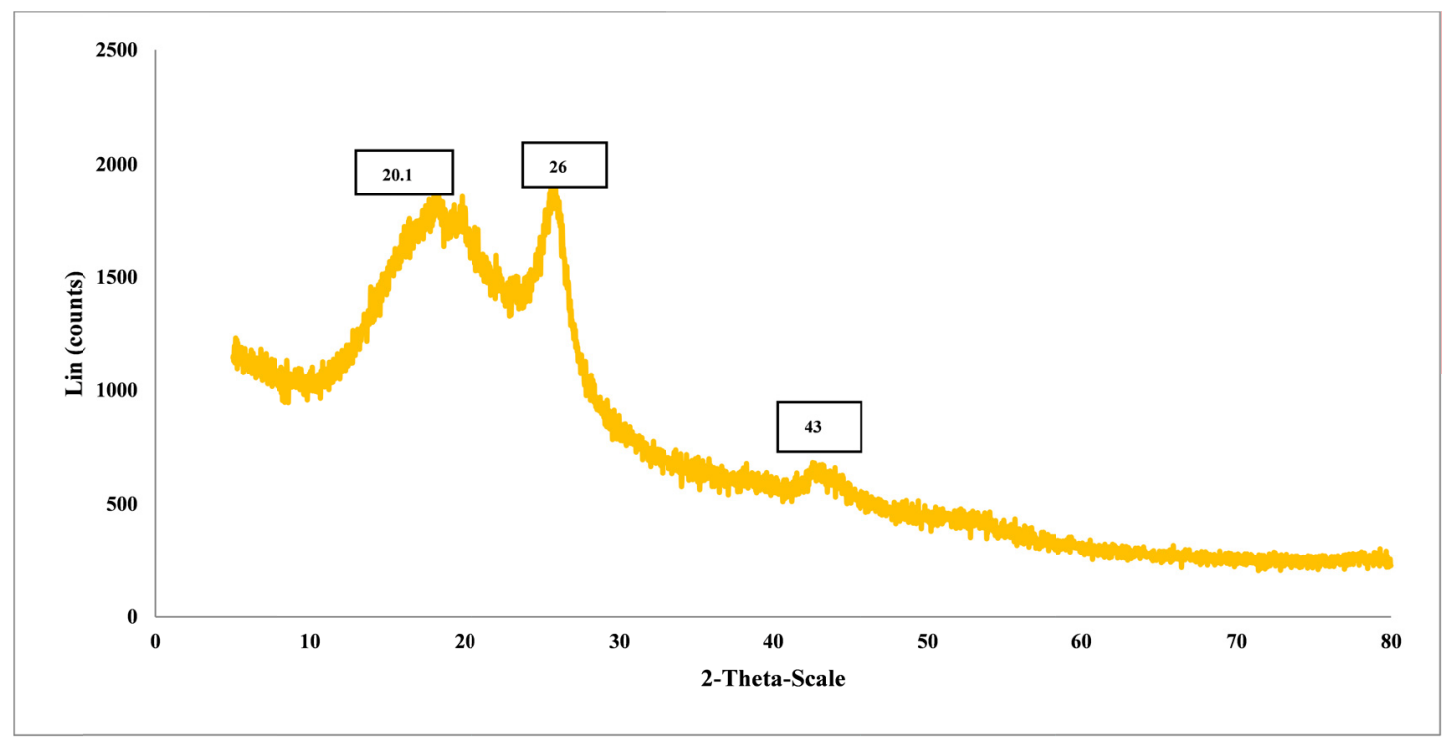

Figure 2. XRD Analysis C90PVdF-HFP10 electrode

In Figure 3 (a, and b), FESEM images of $100 \%$ CPCMWCNTs sample electrode with $90 \%$ CPCMWNTs and 10 wt.\% of P(VdF-HFP) were shown. Pure CPCMWNT exhibits regular, entangled and smooth surface morphology with an average outer diameter of $\sim 30 \mathrm{~nm}$ and length of several micrometers. The few larger tubes that were cited in the FESEM structure indicate that the original MWCNT has been oxidized thereby resulting in the enlargements of the tubes. However, the FESEM image in Figure 3 (b), although was clearer, but it's not as in Figure 3 (a), which is as a result of the addition of $10 \%$ binder into the composition of the electrode. This could be seen even more clearly in Figure 4, where the FESEM images of CPCMWCNTs were taken at different magnifications of (a); $3.6 \mathrm{~mm} \times 50 \mathrm{k}(1 \mu \mathrm{m})(\mathrm{b}) ; 3.6 \mathrm{~mm} \times 100 \mathrm{k}(500 \mathrm{~nm})$ and (c); $3.6 \mathrm{~mm} \times 150 \mathrm{k}(300 \mathrm{~nm})$.

On the hybrid polymer electrolytes parts, Figure 5, first show the FESEM images of HSPE containing $50 \mathrm{wt} \%$ of both PVA and $\mathrm{H}_{3} \mathrm{PO}_{4}$ at a magnification of (a); $3.5 \mathrm{~mm} \times 35 \mathrm{LM}(1.00 \mathrm{~mm})(\mathrm{b}) ; 3.5 \mathrm{~mm} \times 150 \mathrm{LM}(300 \mu \mathrm{m})$ and (c) $3.5 \mathrm{~mm} \times 300 \mathrm{LM}(100 \mu \mathrm{m})$. The entangling nature of the surface of the image was a clear indication of the presence of the filter paper. Except in a few spots, all over the surface of the polymer look unique as the Watman filter paper was coated with composites of both PVA and $\mathrm{H}_{3} \mathrm{PO}_{4}$. The same can also be said to Figure 6. However, in Figure 7 where the FESEM images of HSPE with the content of $70 \mathrm{wt} \% \mathrm{of}_{3} \mathrm{PO}_{4}, 30 \mathrm{wt}$. $\%$ of PVA and at a magnification of (a); $3.5 \mathrm{~mm} \times 35 \mathrm{LM}(1.00 \mathrm{~mm})(\mathrm{b}) ; 3.5 \mathrm{~mm} \times 150 \mathrm{LM}(300 \mu \mathrm{m})$ and (c) $3.5 \mathrm{~mm} \times 300 \mathrm{LM}(100$ $\mu \mathrm{m})$. There appear some obvious changes in the surface morphology. Several places spotted seem to have openings almost everywhere, indication of flaws in the coating. This could result in obtaining a lower capacitance as, the contact between the electrode and the electrolyte could only lead to leaving wider pore sizes that are not in good contacts to each other. Lastly, Figure 8 depicts the FESEM images of C90PVdF-HFP10 electrode overlapped on HSPE containing $60 \mathrm{wt} . \%$ of $\mathrm{H}_{3} \mathrm{PO}_{4}, 40 \mathrm{wt}$. \% at the magnifications of $\mathrm{x} 45 \mathrm{k}(1.00 \mu \mathrm{m})$. The image was taken at an angle of $30^{\circ}$ in order to see the boarder where the electrode and electrolyte interface. Here it can be deduced that, the thinner the electrode the better, so, thicker electrodes will only result in higher internal resistance. 


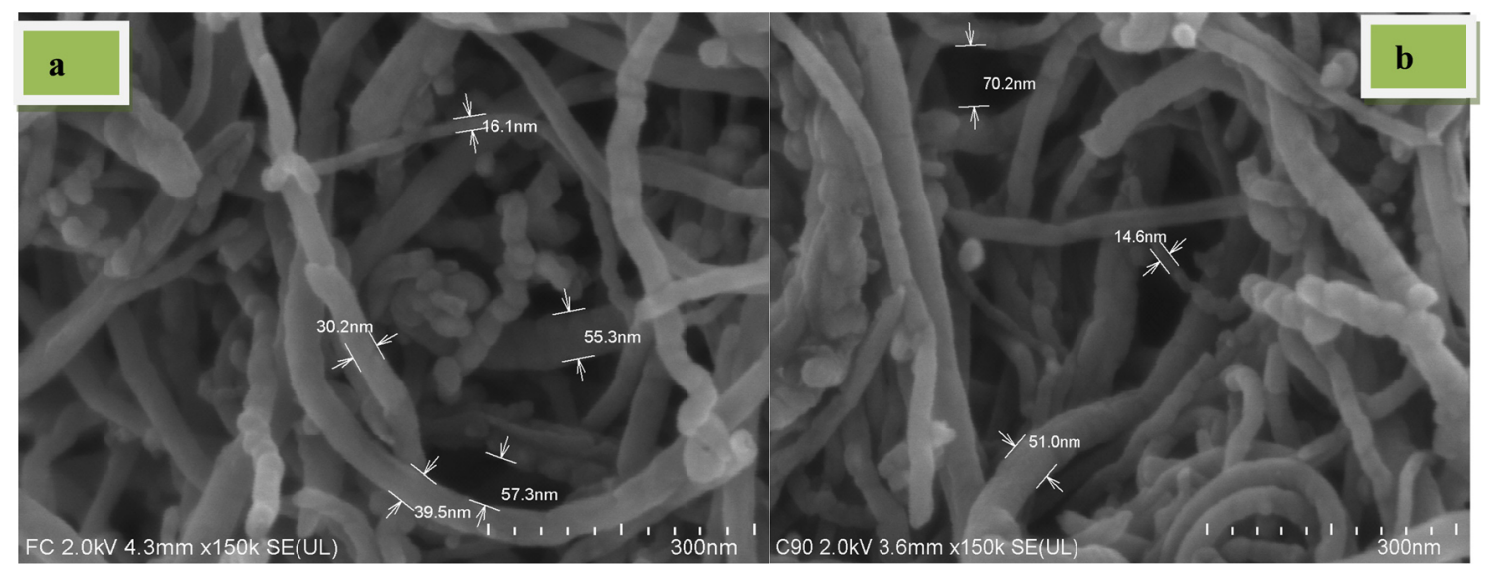

Figure 3. FESEM images of $100 \%$ CPCMWCNTs (a); and (b); sample with $90 \%$ CPCMWNT and 10 wt. \% of P (VdF-HFP) showing average diameters of the pore sizes. The magnifications of the two samples were $4.3 \mathrm{~mm} \mathrm{x}$ $150 \mathrm{k}$ and $3.6 \mathrm{~mm} \times 150 \mathrm{k}$ respectively
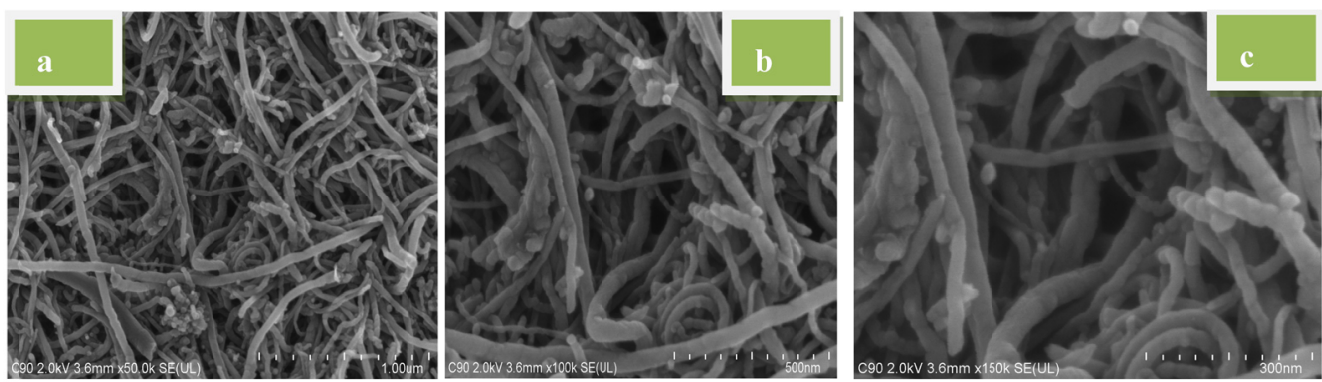

Figure 4. FESEM images of CPCMWCNTs showing C90PVdF-HFP10 electrode at a magnifications of (a); 3.6 $\mathrm{mm} \times 50 \mathrm{k}(1 \mu \mathrm{m})(\mathbf{b}) ; 3.6 \mathrm{~mm} \times 100 \mathrm{k}(500 \mathrm{~nm})$ and (c); $3.6 \mathrm{~mm} \times 150 \mathrm{k}(300 \mathrm{~nm})$
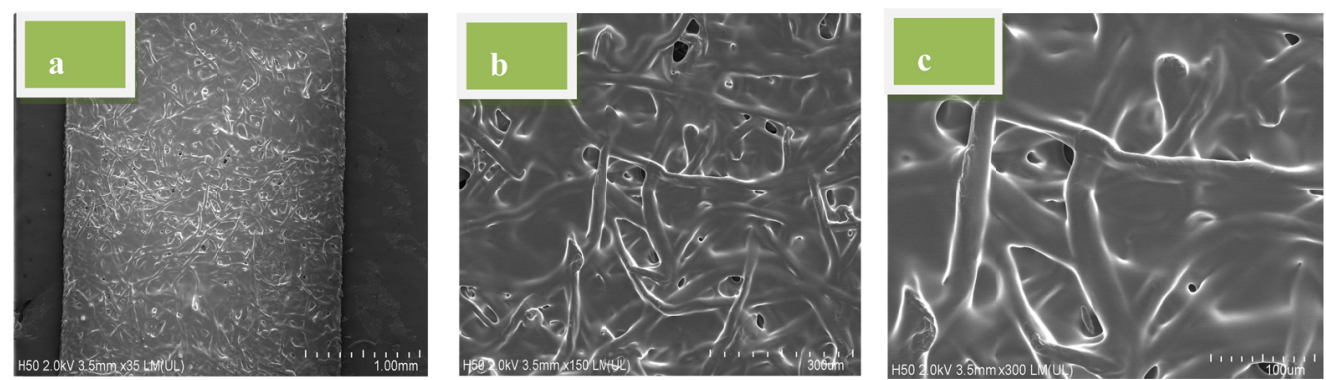

Figure 5. FESEM images of HSPE containing $50 \mathrm{wt}$ \% of both PVA and $\mathrm{H}_{3} \mathrm{PO}_{4}$ at a magnification of (a); $3.5 \mathrm{~mm}$ x $35 \mathrm{LM}(1.00 \mathrm{~mm})(\mathbf{b}) ; 3.5 \mathrm{~mm} \times 150 \mathrm{LM}(300 \mu \mathrm{m})$ and (c); $3.5 \mathrm{~mm} \times 300 \mathrm{LM}(100 \mu \mathrm{m})$
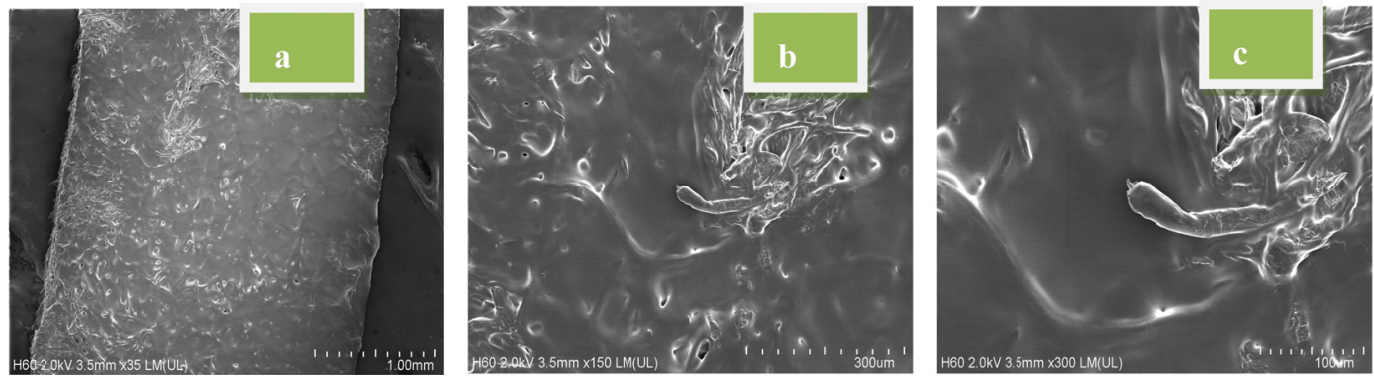

Figure 6. FESEM images of HSPE containing 60 wt. \% of $\mathrm{H}_{3} \mathrm{PO}_{4}, 40 \mathrm{wt}$. \% of PVA at a magnification of (a); 3.5 $\mathrm{mm} \times 35 \mathrm{LM}(1.00 \mathrm{~mm}) \mathbf{( b )} ; 3.5 \mathrm{~mm} \times 150 \mathrm{LM}(300 \mu \mathrm{m})$ and (c); $3.5 \mathrm{~mm} \times 300 \mathrm{LM}(100 \mu \mathrm{m})$. 

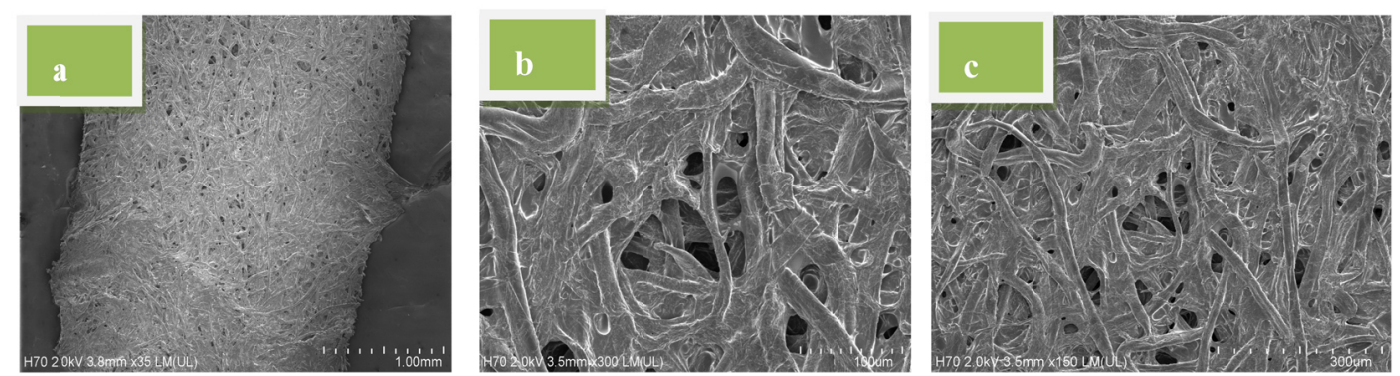

Figure 7. FESEM images of HSPE containing 70 wt. \% of $\mathrm{H}_{3} \mathrm{PO}_{4}, 30$ wt. \% of PVA at a magnification of (a); 3.5 $\mathrm{mm} \times 35 \mathrm{LM}(1.00 \mathrm{~mm})(\mathbf{b}) ; 3.5 \mathrm{~mm} \times 150 \mathrm{LM}(300 \mu \mathrm{m})$ and $(\mathbf{c}) ; 3.5 \mathrm{~mm} \times 300 \mathrm{LM}(100 \mu \mathrm{m})$

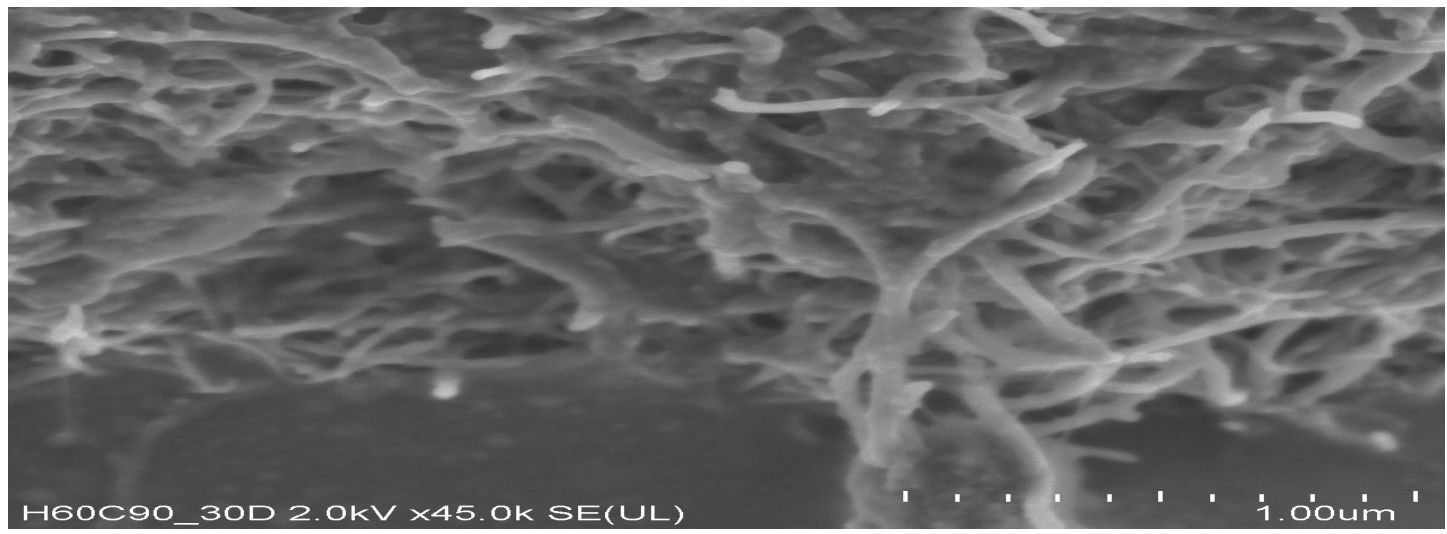

Figure 8. FESEM images of C90PVdF-HFP10 electrode overlapped on HSPE containing 60 wt. $\%$ of $\mathrm{H}_{3} \mathrm{PO}_{4}, 40$ wt. $\%$ at the magnifications of $x 45 \mathrm{k}(1.00 \mu \mathrm{m})$ and an angle of $30^{\circ}$

\subsection{Thermogravimetric Analysis (TGA)}

The thermogravimetric analysis (TGA) was carried out on the scale-range of $50{ }^{\circ} \mathrm{C}$ to $1000{ }^{\circ} \mathrm{C}$ under nitrogen gas $\left(\mathrm{N}_{2}\right)$ flow at a heating rate of $10^{\circ} \mathrm{C} \mathrm{min}^{-1}$ on a METTLER, STAR ${ }^{\mathrm{e}} \mathrm{SW} 10.00$ thermal analyzer in line with our previous work (Hashim et al., 2014). The thermal stability of the samples was discerned in Figure 9. The Figure were (a); $0 \%$ sample (Background) (b); pure CPCWMCNT (c) C90PVdF-HFP10 - Single scale (d); C90PVdF-HFP10 - Double scale.

Before beginning the experiment a background heating was conducted in order to pave way with any ruminant residue and for re-calibration. Trace in Figure 9 (b) shows that, the pure CPCWMCNT experience a major loss of just $11.0719 \%$ occurring at $611.76{ }^{\circ} \mathrm{C}$ leaving a residue of $87.9109 \%$. This result shows that, the pure MWCNT have very good thermal stability and consequently, good in application for electrochemical devices. While in Figure 9 (b and c), it can be noticed that, when the active materials were all incorporated in a single electrode, three losses were then recorded. The initial loss of $2.5224 \%$ of the total samples occurs at $307.24{ }^{\circ} \mathrm{C}$, then the second loss of $5.9640 \%$ was observed at $449.5^{\circ} \mathrm{C}$ and the highest loss of $11.629 \%$ was noticed at $708.84{ }^{\circ} \mathrm{C}$. This shows that, the introduction of active material to the pure CPCWMCNT will work well in the supercapacitor fabrication process. 

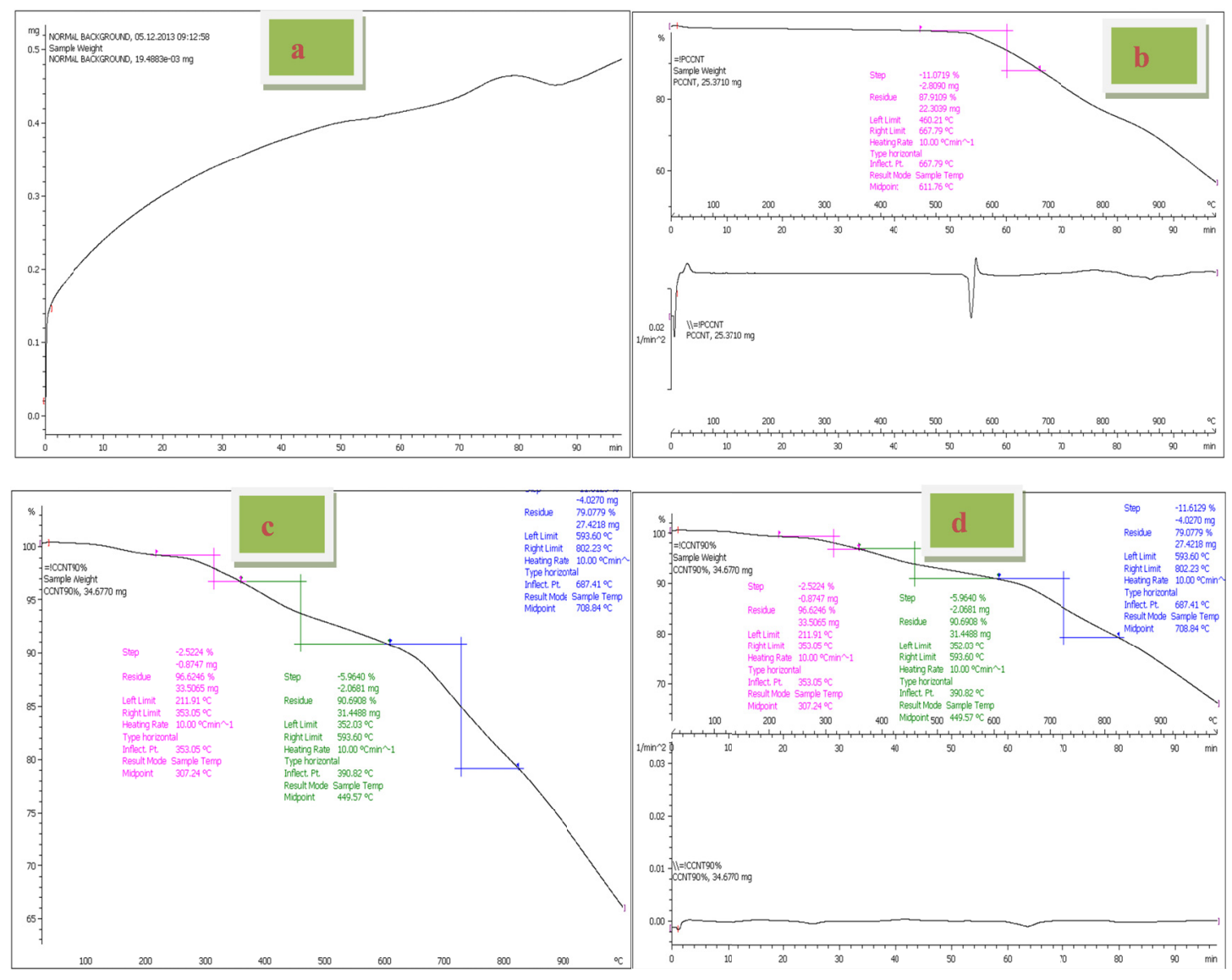

Figure 9. TGA of the electrode at (a); 0 \% sample (Background) (b); pure CPCWMCNT (c); C90PVdF-HFP10 Single scale (d); C90PVdF-HFP10 - Double scale

\subsection{Electrochemical Behavior}

The electrochemical behaviors of CPCWMCNT were investigated by cyclic voltammetry (CV) and CD measurements using two-electrode system. Figure 10 shows a CV of Cell -A (C90PVdF-HFP10 H50| C90PVdF-HFP10) at (a); scan rates of 10, 50 and $100 \mathrm{mV} ; 3 \mathrm{~V}$ - voltage window (b) scan rate of $50 \mathrm{mV} ; 1 \mathrm{~V}-$ voltage window. It can be discerned that at a scan rate of $50 \mathrm{mV}$ and $1 \mathrm{~V}$ - voltage window, the EDLC curve look more rectangular in shape. The specific capacitance of the electrode materials obtained in the two-electrode system was calculated by integrating the CV curves in Figure using the formula;

$$
C_{s p}=\frac{2 i}{s m}
$$

Where $i$ is the current difference, $m$ is the mass of the electrode and $s$ is the scan rate.

It could be obtained that the specific capacitance is $30.1 \mathrm{Fg}^{-1}, 13.5 \mathrm{Fg}^{-1}$, and $11.2 \mathrm{Fg}^{-1}$ for scan rates of 10,50 and $100 \mathrm{mV}$, respectively. This gives an explanation of the relationship between the capacitance and scan rate. The specific capacitance decreases from $30.1 \mathrm{Fg}^{-1}$ to $11.2 \mathrm{Fg}^{-1}$ which could be attributed to the slow transfer of ions on the electrode electrolyte interface (Shu et al., 2013). It can also be due to the un-uniformity of the coated filter paper by the electrolyte as vindicated in the FESEM analysis.

Furthermore, Figure 11 also shows CV of Cell-B (C90PVdF-HFP10 |H60| C90PVdF-HFP10) at (a); scan rates of 1,50 and $100 \mathrm{mV}, 3 \mathrm{~V}$ - voltage window (b) scan rate of $50 \mathrm{mV} ; 1 \mathrm{~V}$ - voltage window. The specific capacitances obtained in this cell were $60.1 \mathrm{Fg}^{-1}, 28.0 \mathrm{Fg}^{-1}$ and $21 \mathrm{Fg}^{-1}$ for scan rates of 10,50 and $100 \mathrm{mV}$ respectively. These results almost double that of cell-A which might be attributed to the increase in ionic conductivity in the polymer electrolyte of the HSPE. And Last but not the least, is the Figure 12, depicting the CV of Cell $-\mathrm{C}$ (C90PVdF-HFP10 |H70| C90PVdF-HFP10) at; (a) Scan rates of 1, 50 and $100 \mathrm{mV}, 3$ V- voltage window, (b) Scan 
rate of $50 \mathrm{mV} ; 1 \mathrm{~V}$ - voltage window. This result represent weakest of all the three cells with the lowest capacitance delivery of $24.0 \mathrm{Fg}^{-1}, 5.6 \mathrm{Fg}^{-1}$ and $2.9 \mathrm{Fg}^{-1}$ obtained for the scan rates of 10,50 and $100 \mathrm{mV}$ respectively. It can be recalled that FESEM analysis of HSPE of this cell shows the poorest coating of the electrolyte as a result very high internal resistance recorded. Table 1 gave a summary report of the capacitance obtained in all the three cells and Figure 13 (a) summarize the capacitance performance in the combined graph of capacitance against the scan rates for Cells A, B and C while Figure 13 (b) revealed the cyclic performances of cell-A (C90PVdF-HFP10 |H50| C90PVdF-HFP10), cell-B (C90PVdF-HFP10 |H60| C90PVdF-HFP10) and cell-C (C90PVdF-HFP10 |H70| C90PVdF-HFP10). Cell-B show a more stable capacitance at about $35 \mathrm{Fg}^{-1}$ up to 5000 cycles, however, both cell-A and $\mathrm{C}$ were shown to maintain their cycleabilities at around $10 \mathrm{Fg}^{-1}$ only. This degradation is attributed the high internal resistance that both the cells exhibited.

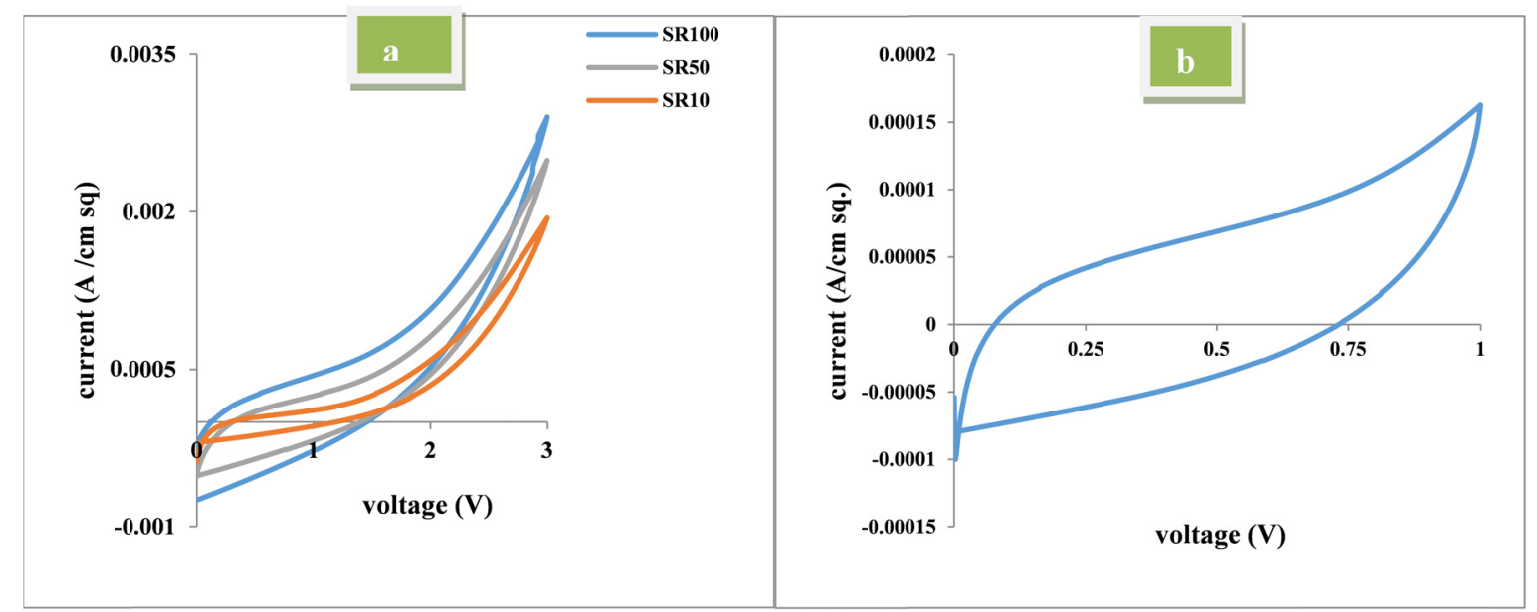

Figure 10. CV of Cell -A (C90PVdF-HFP10 |H50| C90PVdF-HFP10) at (a); scan rates of 1, 50 and $100 \mathrm{mV}, 3 \mathrm{~V}$ voltage window (b); scan rate of $50 \mathrm{mV} ; 1 \mathrm{~V}$ - voltage window

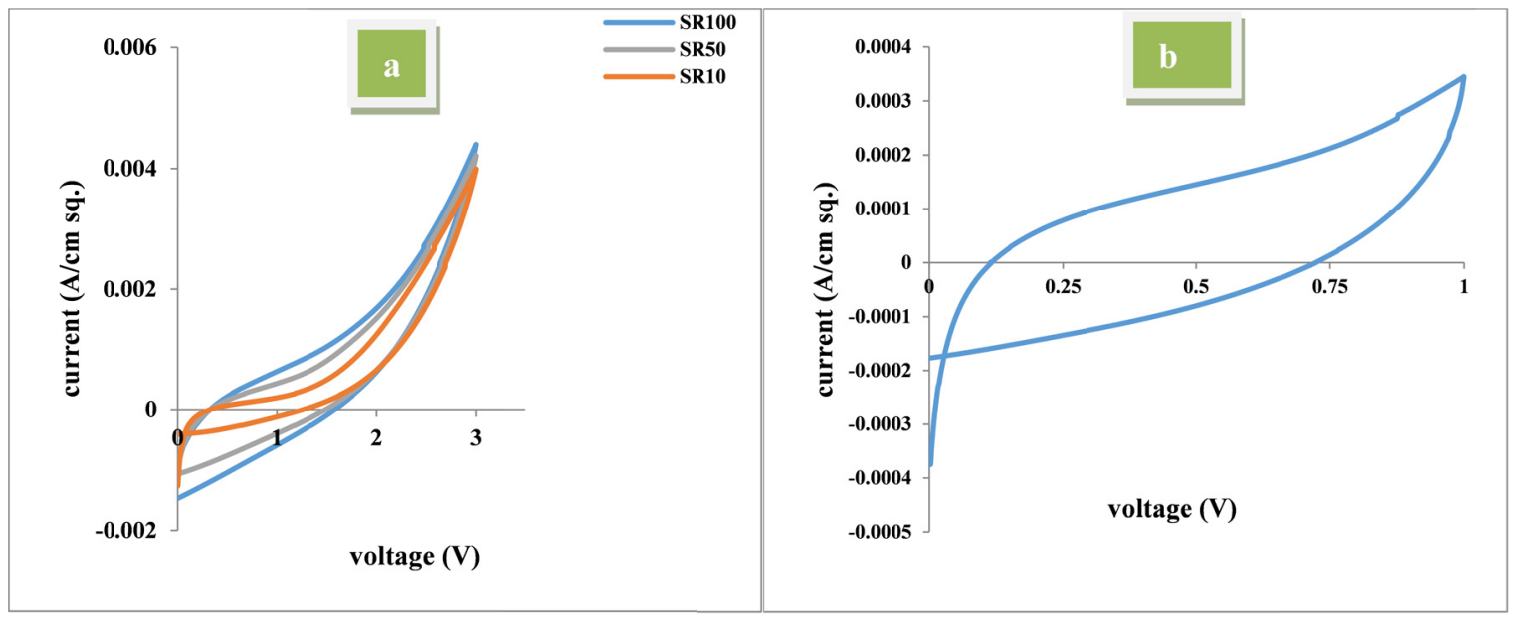

Figure 11. CV of Cell -B (C90PVdF-HFP10 |H60| C90PVdF-HFP10) at (a); scan rates of 1, 50 and $100 \mathrm{mV}, 3$ Vvoltage window (b); scan rate of $50 \mathrm{mV} ; 1 \mathrm{~V}$ - voltage window 


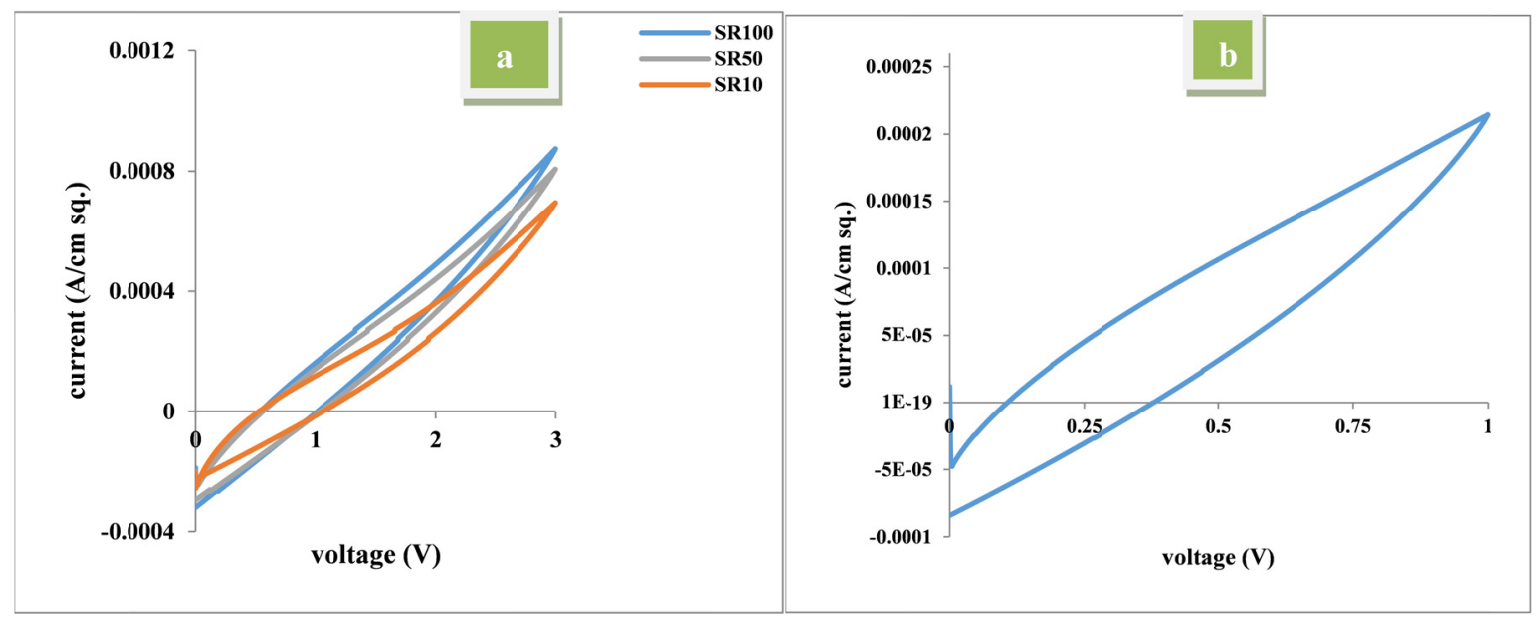

Figure 12. CV of Cell -C (C90PVdF-HFP10|H70| C90PVdF-HFP10) at (a); scan rates of 1, 50 and $100 \mathrm{mV}, 3 \mathrm{~V}$ voltage window (b); scan rate of $50 \mathrm{mV} ; 1 \mathrm{~V}$ - voltage window

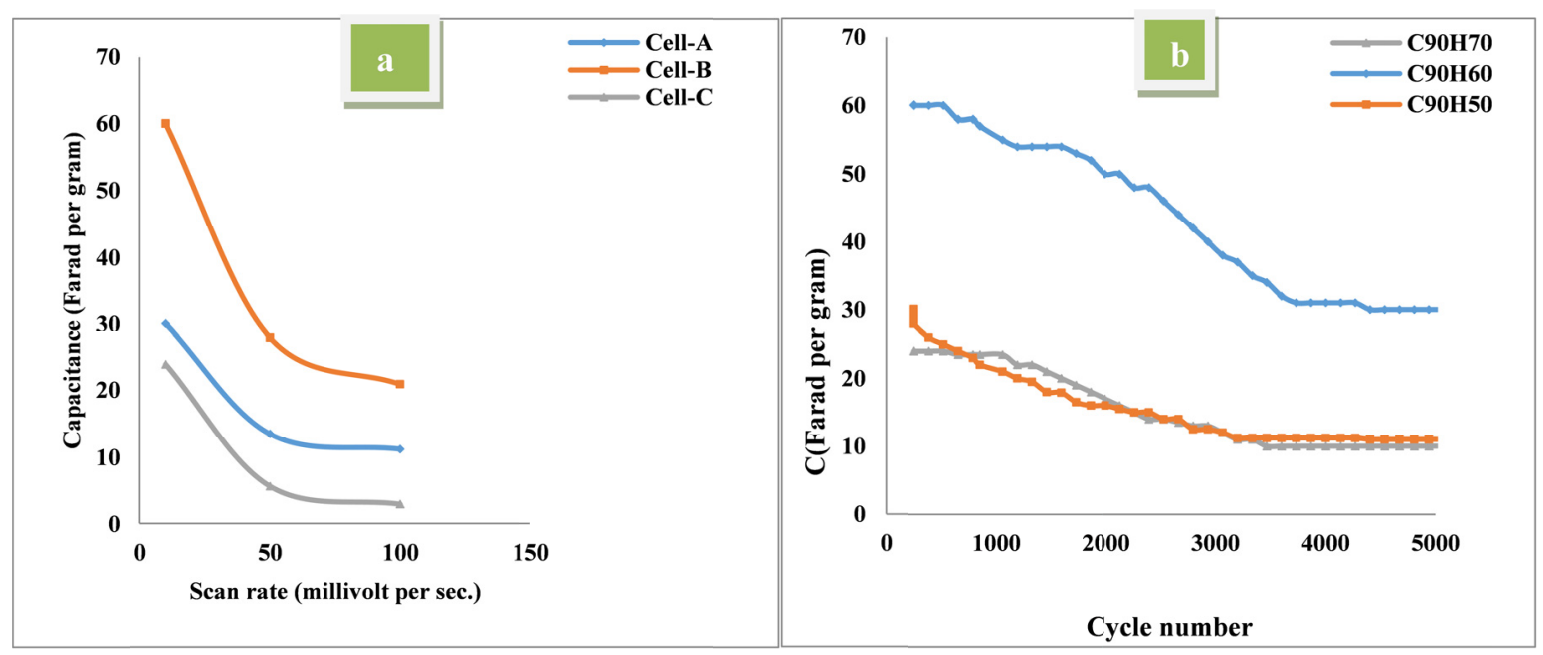

Figure 13. Combined graphs of capacitance against the scan rates and cyclic performances for cells A, B and C

Table 1. Performance of Supercapacitor by the CV

\begin{tabular}{ccccc}
\hline \multirow{2}{*}{ Cells } & \multirow{2}{*}{ Working Voltage $(\mathrm{V})$} & \multicolumn{3}{c}{ Capacitance value of Different scan rates $\left(\mathrm{Fg}^{-1}\right)$} \\
\cline { 3 - 5 } & & $100 \mathrm{mV}$ & $50 \mathrm{mV}$ & $10 \mathrm{mV}$ \\
\hline A-C90H50 & 3 & 11.2 & 13.5 & 30.1 \\
B-C90H60 & 3 & 21.0 & 28.0 & 60.1 \\
C-C90H70 & 3 & 2.9 & 5.9 & 24.0 \\
\hline
\end{tabular}




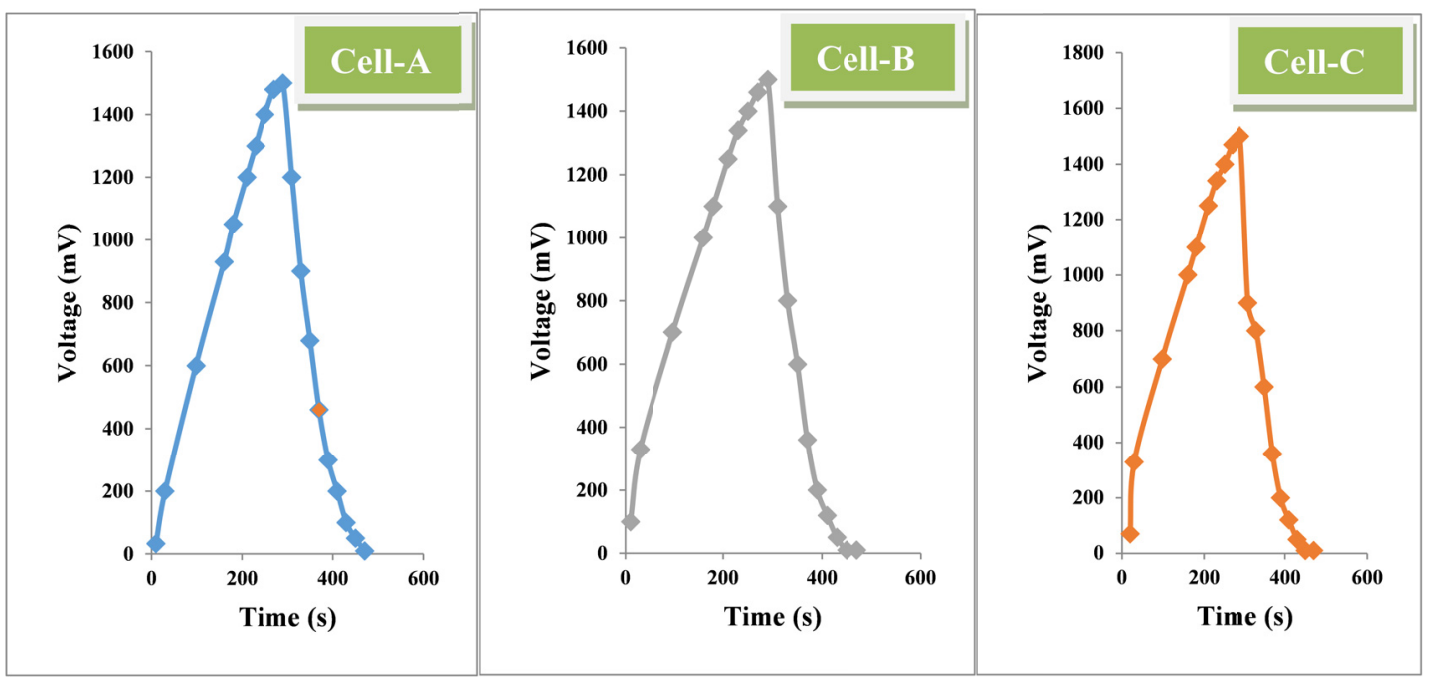

Figure 14. CD graphs of (a); Cell-A (b); Cell-B and (c); Cell- C

Table 2. Performance of Supercapacitor by the CD

\begin{tabular}{lccccc}
\hline Cells & Working Voltage $(\mathrm{V})$ & $\mathrm{C}_{\mathrm{d}}\left(\mathrm{Fg}^{-1}\right)$ & $\mathrm{ESR}\left(\Omega \mathrm{cm}^{2}\right)$ & Energy Density $\left(\mathrm{Jg}^{-1}\right)\left(\mathrm{Jg}^{-1} \mathrm{~s}^{-1}\right)$ & Power Density \\
\hline A-C90H50 & 1.5 & $8.6-86.1$ & $0.15-1.5$ & $43.2-432.2$ & $0.8-8.4$ \\
B-C90H60 & 1.5 & $7.7-76.7$ & $0.2-2.0$ & $38.8-385.3$ & $0.6-6.3$ \\
C-C90H70 & 1.5 & $8.9-89.3$ & $6.6-66.0$ & $44.7-448.4$ & $0.02-0.1$ \\
\hline
\end{tabular}

The galvanostatic $\mathrm{CD}$ test is considered to be an alternative and arguably better quantitative method to evaluate the supercapacitive nature of an electrode material compared to the CV measurement (Shu et al., 2013). In this respect, we determined the capacitance of the supercapacitor cell yet, using this method. In Figure 14, the CD graphs of (a); Cell-A (b); Cell-B and (c); Cell- $\mathrm{C}$ were all depicted at a working voltage of $1.5 \mathrm{~V}$ and at three different current densities i.e. 10, 20 and $100 \mathrm{~mA}$. In addition to effective capacitance, power and energy densities were also calculated using Equations 2, 3 and 4.

For effective capacitance,

$$
C_{e}=i \frac{\Delta t}{\Delta V}
$$

Where $i$ is the applied current and $\Delta t$ and $\Delta V$ are the changes in time and current respectively. For energy and power of the capacitance, we use the following Eqs.;

$$
\begin{aligned}
& E=\frac{1}{2 m} C V^{2} \\
& P=\frac{V^{2}}{4 m E S R}
\end{aligned}
$$

ESR denotes equivalent series resistance, $m$ is the mass of the electrode and $V$ represents the applied voltage (or voltage window). In cell-A, the discharged capacitances obtained were $8.60 \mathrm{Fg}^{-1}, 17.71 \mathrm{Fg}^{-1}$ and $86.06 \mathrm{Fg}^{-1}$ respectively at an applied current density of 100,20 and $10 \mathrm{~mA}$; the calculated energy and power densities are $43.20 \mathrm{Jg}^{-1} / 0.84 \mathrm{Jg}^{-1} \mathrm{~s}^{-1}, 86.42 \mathrm{Jg}^{-1} / 1.67 \mathrm{Jg}^{-1} \mathrm{~s}^{-1}$ and $432.22 \mathrm{Jg}^{-1} / 8.37 \mathrm{Jg}^{-1} \mathrm{~s}^{-1}$ at the said current densities. In cell-B, the discharged capacitances obtained were $7.67 \mathrm{Fg}^{-1}, 15.35 \mathrm{Fg}^{-1}$ and $76.72 \mathrm{Fg}^{-1}$ respectively at an applied current density of 100, 20 and $10 \mathrm{~mA}$; the calculated energy and power densities are $38.77 \mathrm{Jg}^{-1} / 0.63 \mathrm{Jg}^{-1} \mathrm{~s}^{-1}, 77.54$ $\mathrm{Jg}^{-1} / 1.26 \mathrm{Jg}^{-1} \mathrm{~s}^{-1}$ and $385.31 \mathrm{Jg}^{-1} / 6.28 \mathrm{Jg}^{-1} \mathrm{~s}^{-1}$ at the said current densities. And finally cell-C has the following 
results for the capacitance; $8.89 \mathrm{Fg}^{-1}, 17.80 \mathrm{Fg}^{-1}$ and $89.28 \mathrm{Fg}^{-1}$ respectively at an applied current density of 100 , 20 and $10 \mathrm{~mA}$; power/energy densities are $44.70 \mathrm{Jg}^{-1} / 0.02 \mathrm{Jg}^{-1} \mathrm{~s}^{-1}, 89.41 \mathrm{Jg}^{-1} / 0.04 \mathrm{Jg}^{-1} \mathrm{~s}^{-1}$ and $448.40 \mathrm{Jg}^{-1} / 0.19$ $\mathrm{Jg}^{-1} \mathrm{~s}^{-1}$ at the said current densities. From the overall results, it can be observed that, the discharged capacitance decreases with the increase in current density, which could be as a result of the low penetration of ions into the inner region of the pores due to fast potential changes.

\section{Conclusion}

In this work, we have explored the noble of CPCWMCNT used as an electrode for high performance supercapacitors using HPSE as a separator. Three cells were constructed and leveled as cell-A (C90PVdF-HFP10 |H50| C90PVdF-HFP10), cell-B (C90PVdF-HFP10 |H60| C90PVdF-HFP10) and cell-C (C90PVdF-HFP10 |H70| C90PVdF-HFP10) with changes in the separator. The XRD peaks of the sample electrode C90PVdF-HFP10 appeared in $\theta=26^{\circ}$ and $\theta=43^{\circ}$ which might be as a result of the hexagonal structure of $(002)$ and (101) respectively, which also indicates that the carboxyl multiwalled CNT have high conductivity. Again, a wider diffraction at $\theta=20.1^{\circ}$ which correspond to crystalline peaks of PVDF. TGA traces shows that, the pure CPCWMCNT experience a major loss of just $11.0719 \%$, which occurred at $611.76^{\circ} \mathrm{C}$ leaving a residue of $87.9109 \%$, which also shows that, the pure MWCNT have very good thermal stability and consequently, good in application for electrochemical devices. This result, even gets better when the active material was added. From the overall results for the electrochemical analysis of the $\mathrm{CV}$, cell-B delivered higher capacitance of $60.10 \mathrm{Fg}^{-1}$ doubling that of cell-A, and tripling cell-C. Also in $\mathrm{CD}$ analysis with much lower voltage window of $1.5 \mathrm{~V}$, cell-A delivered slightly better than $\mathrm{B}$ and $\mathrm{C}$ with a balanced and better discharge capacitance of $86.06 \mathrm{Fg}^{-1}$ with higher energy/power densities of $432.22 \mathrm{Jg}^{-1} / 8.37 \mathrm{Jg}^{-1} \mathrm{~s}^{-1}$ and lowest in terms of internal resistance.

\section{Acknowledgements}

My sincere gratitude and appreciations goes to the management of the Faculty of Science and Technology USIM under which ERGS grant (USIM/ERGS-FST-52-50111) has been provided for the purpose of this research.

\section{Reference}

Aravinda, L. S., Bhat, K. U., \& Bhat, B. R. (2013). Nano $\mathrm{CeO}_{2} /$ activated Carbon Based Composite Electrodes for High Performance Supercapacitor. Materials Letters, 112, 158-161. http//dx.doi.org/10.016/j.matlet. 2013.09.009

Aravinda, L.S., Bhat, U., \& Bhat, B. R. (2013). Binder Free $\mathrm{MoO}_{3} /$ multiwalled Carbon Nanotube Thin Film Electrode for High Energy Density Supercapacitors. Electrochimica Acta, 112, 663-669. http//dx.doi.org/ 10.1016/j.electacta.2013.08.114

Ayad, M. Y., Becherif, M., \& Henni, A. (2011). Vehicle Hybridization with Fuel Cell, Supercapacitors and Batteries by Sliding Mode Control. Renewable Energy, 36, 2627-2634. http//dx.doi.org/10.1016/j.renene. 2010.06.012

Burke, A. (2009). Capacitors Application. Encyclopedia of Electrochemical Power Sources, l, 685-694. http//dx.doi.org/10.1016/B978-044452745-5.00357-9

Capek, I. (2009). Dispersions, Novel Nanomaterial Sensors and Nanoconjugates Based on Carbon Nanotubes". Advances in Colloid and Interface Science, 150, 63-89. http//dx.doi.org/ 10.1016/j.cis.2009.05.006

Choi, H. J., Jung, S. M., Seo, J. M., Chang, D. W., Dai, L., \& Jong-Beom, B. (2012). Graphene for Energy Conversion and Storage in Fuel Cells and Supercapacitors. Nano Energy, 1, 534-551. http//dx.doi.org/ 10.1016/j.nanoen.2012.05.001

Domingo-García, M., Fernández, J. A., Almazán-Almazána, M. C. López-Garzóna, F. J., Stoecklic, F., \& Centenob, T. A. (2010). Poly(ethylene terephthalate)-based carbons as electrode material in supercapacitors. Journal of Power Sources, 195, 3810-3813. http//dx.doi.org/ 10.1016/j.jpowsour.2009.12.090

Dong, B., He, B., Xu, C., \& Li, H. (2007). Preparation And Electrochemical Characterization Of Polyaniline/Multi-Walled Carbon Nanotubes Composites For Supercapacitor. Material Sci. and Engineering, 143, 7-13. http//dx.doi.org/ 10.1016/j.mseb.2007.06.017

Dubal, D. P., Jagadale, A. D., \& Lokhande, C. D. (2012). Big as well as light weight portable, $\mathrm{Mn}_{3} \mathrm{O}_{4}$ based symmetric supercapacitive devices: Fabrication, performance evaluation and demonstration. Electrochimica Acta, 80, 160-170. 
Dumortier, H., Lacotte, S., Pastorin, G., Marega, R., Wu, W., Bonifazi, D., \& Bianco, A. (2006). Functionalized carbon nanotubes are non-cytotoxic and preserve the functionality of primary immune cells. Nano letters, $6(7), 1522-1528$.

Gund, G. S., Dubal, D. P., Patil, B. H., Shinde, S. S., \& Lokhande, C. D. (2013). Enhanced activity of chemically synthesized hybrid graphene oxide $/ \mathrm{Mn}_{3} \mathrm{O}_{4}$ composite for high performance supercapacitors. Electrochimica Acta, 92, 205-215.

Hashim, M. A., \& Khiar, A. S. A. (2011). Supercapacitor Based On Activated Carbon and Hybrid Polymer Electrolyte. Material Research Innovations., 15, s63-s66.

Hsieh, T. F., Chuang, C. C., Chen, W. J., Huang, J. H., Chen, W. T., \& Chi-Min, S. (2012). Hydrous Ruthenium Dioxide/Multi-walled Carbon-nanotube/titanium Electrodes for Supercapacitors. Carbon, 50, 740-1747. http//dx.doi.org/ 10.1016/j.carbon.2011.12.017

Inagaki, M., Kang, F., Toyoda, M., \& Konno, H. (2014). Chapter 15 - Carbon Materials for Adsorption of Molecules and Ions, In Advanced Materials Science and Engineering of Carbon. Inagaki, M. Kang, F., Toyoda M., \& H. Konno, Butterworth-Heinemann, Boston, (Comp. \& ed.). Advanced Materials Science and Engineering of Carbon, 335-361. http//dx.doi.org/ 10.1016/B978-0-12-407789-8.00015-6

Inagaki, M., Kang, F., Toyoda M., \& Konno, H. (2014). Chapter 1 - Introduction, In Advanced Materials Science and Engineering of Carbon. Inagaki, M. Kang, F., Toyoda M., \& H. Konno, Butterworth-Heinemann, Boston, (Comp. \& ed.). Advanced Materials Science and Engineering of Carbon., 1-13. http//dx.doi.org/ 10.1016/B978-0-12-407789-8.00001-6

Inagaki, M., Kang, F., Toyoda M., \& Konno, H. (2014). Chapter 10 - Nanoporous Carbon Membranes and Webs, In Advanced Materials Science and Engineering of Carbon. Inagaki, M. Kang, F., Toyoda M., \& H. Konno, Butterworth-Heinemann, Boston, (Comp. \& ed.). Advanced Materials Science and Engineering of Carbon., 215-236. http//dx.doi.org/ 10.1016/B978-0-12-407789-8.00010-7

Inagaki, M., Kang, F., Toyoda M., \& Konno, H. (2014). Chapter 11 - Carbon Materials for Electrochemical Capacitors, In Advanced Materials Science and Engineering of Carbon. Inagaki, M. Kang, F., Toyoda M., \& H. Konno, Butterworth-Heinemann, Boston, (Comp. \& ed.). Advanced Materials Science and Engineering of Carbon, 237-265. http//dx.doi.org/ 10.1016/B978-0-12-407789-8.00011-9

Inagaki, M., Kang, F., Toyoda M., \& Konno, H. (2014). Chapter 12 - Carbon Materials in Lithium-ion Rechargeable Batteries, In Advanced Materials Science and Engineering of Carbon. Inagaki, M. Kang, F., Toyoda M., \& H. Konno, Butterworth-Heinemann, Boston, (Comp. \& ed.). Advanced Materials Science and Engineering of Carbon, 267-287. http//dx.doi.org/ 10.1016/B978-0-12-407789-8.00012-0

Inagaki, M., Kang, F., Toyoda M., \& Konno, H.. (2014). Chapter 9 - Carbon Foams, In Advanced Materials Science and Engineering of Carbon. Inagaki, M. Kang, F., Toyoda M., \& H. Konno, Butterworth-Heinemann, Boston, (Comp. \& ed.). Advanced Materials Science and Engineering of Carbon, 189-214. http//dx.doi.org/ 10.1016/B978-0-12-407789-8.00009-0

Iwama, E., Taberna, P.L., Azais, P., Brégeon, L. \& Simon, P. (2012). Characterization of Commercial Supercapacitors for Low Temperature Applications. Journal of Power Sources, 219, 235-239. http//dx.doi.org/10.1016/j.jpowsour.2012.07.029

Jiang, L., Vangari, M., Pryor, T., Xiao, Z., \& Korivi, N. S. (2013). Miniature Supercapacitors Based on Nanocomposite Thin Films. Microelectronic Engineering, 111, 52-57. http//dx.doi.org/10.1016/j.mee.2013. 01.030

Li, Q., Li, Z., Lin, L., Wang, X. Y., Wang, Y., Zhang, C., \& Wang, H. (2010). Facile Synthesis of Activated Carbon/Carbon Nanotubes Compound For Supercapacitor Application. Chemical Engineering Journal, 156, 500-504. http//dx.doi.org/ 10.1016/j.cej.2009.10.025

Mittal, V. (2011). Surface Modification of Nanotube Fillers. Wiley-VCH Verlag GmbH \& Co. KGaA, 1, 1-23.

Paul, S., Choi, K. S., Lee, D. J., Sudhagar, P., \& Yong Soo, K. (2012). Factors Affecting the Performance of Supercapacitors Assembled with Polypyrrole/multi-walled Carbon Nanotube Composite Electrodes. Electrochimica Acta, 78, 649-655.

Payman, A., Pierfederici, S., \& Meibody-Tabar, F. (2008). Energy Control of Supercapacitor/Fuel Cell Hybrid Power Source. Energy Conversion and Management, 49, 1637-1644. http//dx.doi.org/10.1016/j.enconman. 2007.11.012 
Prato, M., Kostarelos, K., \& Bianco, A. (2008). Functionalized Carbon Nanotubes In Drug Design And Discovery. Accounts Of Chemical Research, 41, 60-68.

Pröbstle, H., Schmitt, C., \& Fricke, J. (2002). Button Cell Supercapacitors with Monolithic Carbon Aerogels. Journal of Power Sources, 105(2), 189-194.

Shi, S., Xu, C., Yang, C., Li, J., Du, H., Li, B., \& Feiyu, K. (2013). Flexible Supercapacitors. Particuology, 11, 371-377. http//dx.doi.org/10.1016/S0378-7753(01)00938-7

Shu, D., Lv, C., Cheng, F., He, C., Yang, K., Nan, J., \& Long, L. (2013). Enhanced Capacitance and Rate Capability of Nanocrystalline VN as Electrode Materials for Supercapacitors . Int. J. Electrochem. Sci, 8, 1209-1225.

Snook, G. A., Kao, P., \& Adam, S. (2011). Best, Conducting-Polymer-Based Supercapacitor Devices and Electrodes. Journal of Power Sources, 196, 1-12. http//dx.doi.org/ 10.1016/j.jpowsour.2010.06.084

Stolarska, M., Niedzicki, L., Borkowska, R., Zalewska, A., \& Wieczorek, W. (2007). Structure, transport properties and interfacial stability of $\mathrm{PVdF} / \mathrm{HFP}$ electrolytes containing modified inorganic filler. Electrochimica Acta, 53, 1512-1517.

Tran, C., \& Vibha., K. (2013). Fabrication of Porous Carbon Nanofibers with AdjusTable Pore Sizes as Electrodes for Supercapacitors. Journal of Power Sources, 235, 289-296. http//dx.doi.org/10.1016/j.jpowsour.2013.01. 080

Van Hooijdonk, E., Bittencourt, C., Snyders, R., \& Colomer, J. F. (2013). Functionalization of vertically aligned carbon nanotubes. Beilstein J Nanotechnol, 4, 129-52.

Wang, H., Li, Z., Tak, J. K., Holt, C. M. B., Tan, X., Xu, Z., ... David, M. (2013). Supercapacitors Based on Carbons with Tuned Porosity Derived from Paper Pulp Mill Sludge Biowaste. Carbon, 57, 317-328. http//dx.doi.org/ 10.1016/j.carbon.2013.01.079

Wu, T. H., Chu, Y. H., Hu, C. C., \& Laurence, J. H. (2013). Criteria Appointing the Highest Acceptable Cell Voltage of Asymmetric Supercapacitors. Electrochemistry Communications, 27, 81-84.

Wu, Y., Zhang, T., Zhang, F., Wang, Y., Ma, Y., Huang, Y., Liu, Y., \& Yongsheng, C. (2012). In Situ Synthesis of Graphene/Single-walled Carbon Nanotube Hybrid Material by Arc-Discharge and Its Application in Supercapacitors. Nano Energy, 1, 820-827. http//dx.doi.org/ 10.1016/j.nanoen.2012.07.001

Zheng, C., Qian, W., Cui, C., Zhang, Q., Jin, Y., Zhao, M., Tan, P., \& Wei, F. (2012). Hierarchical Carbon Nanotube Membrane with High Packing Density and Tunable Porous Structure for High Voltage Supercapacitors. Carbon, 50, 5167-5175. http//dx.doi.org/ 10.1016/j.carbon.2012.06.058

\section{Copyrights}

Copyright for this article is retained by the author(s), with first publication rights granted to the journal.

This is an open-access article distributed under the terms and conditions of the Creative Commons Attribution license (http://creativecommons.org/licenses/by/3.0/). 